\title{
1 Permafrost map for Norway, Sweden and Finland
}

2 Gisnås K. ${ }^{1}$, B. Etzelmüller ${ }^{1}$, C. Lussana ${ }^{2}$, J. Hjort ${ }^{3}$, A.B.K. Sannel ${ }^{4}$, K. Isaksen ${ }^{2}$, S.

3 Westermann $^{1}$, P. Kuhry ${ }^{4}$, H. H. Christiansen ${ }^{5}$, A. Frampton ${ }^{4}$ and J. Åkerman ${ }^{6}$.

${ }^{1}$ University of Oslo, Norway

${ }^{2}$ Norwegian Meteorological Institute, Norway

${ }^{3}$ University of Oulu, Finland

${ }^{4}$ Stockholm University, Sweden

${ }^{5}$ The University Centre in Svalbard, Norway

${ }^{6}$ Lund University, Sweden

Corresponding author: Kjersti Gisnås (kjersti.gisnas@geo.uio.no)

\section{Abstract}

The thermal regime of permafrost is sensitive to changes in the climate system. A common, research-based understanding of the permafrost distribution at a sufficient spatial resolution is important to meet scientific, educational and societal demands. We present a new permafrost map for Norway, Sweden and Finland providing a more detailed and updated description of the permafrost distribution in this area. The CryoGRID1 model is implemented at $1 \mathrm{~km}^{2}$ resolution, forced by a new operationally gridded dataset of daily air temperature and snow cover for Finland, Norway and Sweden. 100 model realizations are run for each grid cell, based on statistical snow distributions, allowing for the representation of sub-grid variability of ground temperatures. The new map indicates a total permafrost area (palsas excluded) of $23400 \mathrm{~km}^{2}$ in equilibrium with the average $1981-2010$ climate, corresponding to $2.2 \%$ of the total land area. About $56 \%$ of the area is within Norway, $35 \%$ in Sweden, and $9 \%$ in Finland. The model results are thoroughly evaluated, both quantitatively and qualitatively, as a collaboration project including permafrost experts in the three countries. Observed ground temperatures from 25 boreholes are within $\pm 2{ }^{\circ} \mathrm{C}$ from the average modelled grid cell ground 
temperature, and all are within the range of the modelled ground temperature for the corresponding grid cell. The model results are also evaluated qualitatively by the representatives conducting field investigations on permafrost at several sites within the three countries, and are shown to reproduce observed lower altitudinal limits of permafrost and permafrost distributions mapped by the corresponding detailed field investigations.

\section{Introduction}

Permafrost has gained wide attention because of its sensitivity to climate change. With increasing surface temperatures, permafrost may degrade, with associated consequences like increased release of carbon to the atmosphere (Schuur et al., 2008; Elberling et al., 2010) or increased slope instability in mountain areas (Krautblatter et al., 2013). Knowledge about the spatial distribution and temperatures of permafrost is crucial for several reasons, in particular as a baseline for validation of global and regional climate models and associated land surface models, and as a tool for planning of human activities.

Permafrost, defined as ground remaining at or below $0{ }^{\circ} \mathrm{C}$ for two or more consecutive years (French 2007), is not necessarily visible on the ground surface as it is solely a thermally defined phenomenon, corresponding to the subsurface regime below the active layer. It is therefore important to establish a common, research-based understanding of the permafrost distribution at a sufficiently high spatial resolution to meet scientific and societal demands. The first Northern Hemisphere permafrost map was the "International Permafrost Association Circum-Arctic Map of Permafrost and Ground Ice Conditions" (hereafter the IPA map) by Brown et al. (1997), with a scale of 1:10,000,000. This map was produced by gathering information from researchers working with permafrost in all different permafrost areas. Today the map has been widely used as a baseline for validating modelled permafrost in the northern hemisphere based on both global and regional Circulation models. It provides 
information of the spatial distribution of permafrost along with potential ground ice content, and is mainly based on experience and field observations. Because of the coarse map scale it has only limited application in regional areas, such as the Scandinavian Peninsula. In this region, numerous field-based studies have been conducted since the 1980s, including the establishment of around 30 new permafrost boreholes during the International Polar Year 2007-2009 (IPY) (Isaksen et al., 2001; Christiansen et al., 2010; Farbrot et al., 2011; Sannel et al., 2015). The new knowledge draws a more differentiated image of the permafrost distribution, justifying the production of a separate and more detailed regional permafrost map of this region.

A main objective for a new baseline map is to provide an improved regional-scale description of the current state of permafrost with greater accuracy and detail. The map should serve as a useful and reliable tool for both the cryosphere research community and practitioners interested in the state of permafrost in the area. A new map should therefore also to the largest extent possible be based on observations. For permafrost, this includes primarily the forcing climate parameters such as air temperature and snow conditions, along with modulating parameters such as the type of surface cover and soil thermal properties. To achieve the desired spatial resolution of ground temperatures, climate information must be transferred to soil temperatures and thus permafrost distribution. A model used for this purpose should be robust enough to give trustworthy results, and simple enough to have relevant input parameters over a larger area, preferably through field observations. In a second step, the resulting permafrost distribution must be validated with field information in several different areas, to reduce the spatial bias.

Here, we present a new permafrost map for the Norway, Sweden and Finland providing a detailed description of the permafrost distribution in this area, following the objectives mentioned above. The map is obtained by applying a simple numerical equilibrium model, the 
CryoGRID1 (Farbrot et al., 2011; Gisnås et al., 2013), forced with $1 \mathrm{~km}^{2}$ gridded data on daily air temperature and snow cover for the period $1981-2010$ based on the recently developed Nordic Gridded Climate Data set (NGCD, http://blog.fmi.fi/nordmet/node/100). The CryoGRID1 model uses a limited set of parameters, mainly to describe the temperature offsets between air, ground surface and ground temperatures. These parameters were refined for snow and mires (including palsas) based on extensive field measurements. The model results are qualitatively evaluated by national permafrost experts with active field research sites, and compared to the available ground and ground surface temperature observations, "Bottom temperature of snow" (BTS, Haeberli (1973))-surveys and geomorphological maps showing permafrost landforms such as palsas, intact rock glaciers and stable ice-cored moraines. Finally, changes in the modelled permafrost distribution over the period 1981-2010 are evaluated.

\section{Setting}

Norway, Sweden and the north-western part of Finland form together the Scandinavian

Peninsula. In the following we also include the remaining parts of Finland under the Scandinavian Peninsula, giving in a total land area of the peninsula of $1.111 .890 \mathrm{~km}^{2}$. The geology of the peninsula consists of a stable large crust of very old metamorphic rock (c. 2500-3100 Ma old). The bedrock in most of northern and central Sweden, together with the south-western parts of Finland, was formed during the Svecofennian orogeny (1750-1900 Ma ago). The Scandinavian Caledonides or the Scandes, stretching through most of Norway and adjacent parts of Sweden, form the highest mountains of Scandinavia, with peaks up to 2469 m a.s.l. (Galdhøpiggen, Norway). The mountain chain consists of metasedimentary and metavolcanic rocks, deposited in the predecessor of the present-day Atlantic Ocean c. 700 to $400 \mathrm{Ma}$ ago, together with slices of older basement. These rocks were thrust several $100 \mathrm{~km}$ 
eastwards over the edge of the Fennoscandian Shield when it collided with North America and Greenland during the Caledonian orogeny c. 400 Ma ago. During the opening of the Atlantic Ocean in the Tertiary, the margin of Scandinavia was tilted, with the highest land heave in the west (see e.g. summary by Gabrielsen et al. (2010)).

The present topography of Scandinavia is a result of subsequent modulation by multiple glaciations the last 3 Ma years, while the sediment cover over the bedrock is mostly related to the last one or two major glaciations (Gabrielsen et al., 2010). This has resulted in a large variety of landscapes on the peninsula. Pre-existing mountain river systems in the west were linearly carved by the glaciers, producing the present fjord landscape. Remains of the paleic surfaces were preserved both between the fjord systems and towards the east, indicating coldbased and non-erosive conditions during at least the latter glaciations. In some areas, local glaciations have dominated over longer time periods, leaving alpine relief forms.

The superficial deposits in Scandinavia are governed by the architecture and deglaciation pattern of the Pleistocene ice sheets. Only c. $43 \%$ of the land area is today covered by till(Ramberg et al., 2006). In high mountain areas, exposed bedrock and only thin covers of till or regolith dominate, while valleys are often filled with glacio-lacustrine, glacio-fluvial and fluvial sediments. Over certain elevation limits, depending on latitude and distance from the coast, mountain slopes and plateaus are covered by coarse block fields. These block fields can be several meters thick, with coarse boulders overlying finer sediments. The origin of these block fields is disputed, but most likely they are remnants from a combination of preglacial weathering along with Pleistocene frost processes occurring above glacial trimlines (Ballantyne, 2010). During the Holocene, a climatic shift towards warmer and wetter conditions favoured the accumulation of organic material in wetlands. This material covers wide areas in central and especially northern Scandinavia. Both the block fields and the organic material play crucial roles for the thermal regime and distribution of permafrost. 
124 The present $(1981$ - 2010) climate in Scandinavia is highly variable, with mean annual air

125 temperatures $(M A A T)$ of up to $9^{\circ} \mathrm{C}$ in the maritime areas along the coast and in the

126 southernmost parts (Figure 1). The highest parts of the Scandes (> $2000 \mathrm{~m}$ ) feature MAAT

127 below $-5^{\circ} \mathrm{C}$. In the northernmost parts of Finnmark MAATs are often below $0{ }^{\circ} \mathrm{C}$ all the way

128 down to sea level. The Scandes represents a significant orographic barrier for the prevailing

129 westerly winds from the Atlantic Ocean, creating a strong east-west gradient in the annual

130 precipitation pattern. This results in average maximum snow depths of 2 to 6 meters in the

131 western parts of the mountains (average over 1981 - 2010), while on the eastern side

132 maximum snow depths are normally 2 meters or less. Further east of the Scandes the

133 maximum snow depths averaged over $1 \mathrm{~km}^{2}$ are generally below 1 meter, according to the

134 snow depth data based on the NGCD dataset (Figure 1).

\section{3. Permafrost in Scandinavia}

136 The majority of the permafrost in both Norway and Sweden is found in mountainous settings

137 (e.g. Etzelmüller et al., 2003; Gisnås et al., 2013). However, in the northern parts of

138 Scandinavia, much of the permafrost is located in mires, often producing palsa landforms and

139 peat plateaus, signifying sporadic permafrost distribution (e.g. King and Seppälä, 1987; Sollid

140 and Sorbel, 1998; Johansson et al., 2006; Borge et al., 2016). While permafrost was suggested

141 present in the Scandinavian mountains already in the beginning of the $19^{\text {th }}$ century (Reusch,

142 1902), its wide distribution in the mountains was not recognized until extensive studies were

143 carried out by King (King, 1982; 1986; King and Seppälä, 1987; King and Åkerman, 1993) in

144 both southern and northern Scandinavia. Before these fundamental studies, permafrost was

145 mainly thought to be related to palsa mires (Reusch, 1902), which are wide-spread from sea

146 level and up to 1000 meters north of approximately $68^{\circ} \mathrm{N}$ in both Norway, Finland and

147 Sweden (Figure 2). 
148 Since the late 1980s, permafrost studies have followed different directions in Norway,

149 Sweden and Finland. In Sweden and Finland much focus was directed towards sporadic 150 permafrost, mostly related to palsas (e.g. Seppälä, 1997). In Abisko (northern Sweden),

151 Åkerman and Johansson (2008) established a monitoring station for active layer thickness,

152 which has been in operation since 1978. In Norway, a first $10 \mathrm{~m}$ borehole in permafrost was

153 drilled at Juvvasshøe (southern Norway) in 1982 (Ødegård et al., 1992). This was the start of

154 a more systematic mapping of mountain permafrost in southern Norway (Ødegård et al.,

155 1996; Isaksen et al., 2002), to a large degree based on BTS-surveys (e.g. Ridefelt et al.,

156 2008). In 1999 and 2000 the EU-funded PACE project (Harris et al., 2001) funded two deep

157 boreholes in Scandinavia (at Juvvasshøe and at Tarfalaryggen), described in Isaksen et al.

158 (2001) and Sollid et al. (2000). These boreholes boosted the mountain permafrost research in

159 Scandinavia, and a borehole monitoring network was established in southern Norway (Sollid

160 et al., 2003; Farbrot et al., 2011). During the IPY monitoring networks were also built up in

161 northern Norway, northern Sweden and Finland, along with Svalbard (Christiansen et al.,

162 2010).

163 From these studies, an improved understanding of the permafrost distribution in Scandinavia

164 is obtained, as outlined in Figure 2. The southernmost observation of permafrost in

165 Scandinavia is reported from Gaustadtoppen in southern Norway $\left(59.9^{\circ} \mathrm{N}\right)$, with frozen

166 bedrock down to $1500 \mathrm{~m}$ a.s.l. (Etzelmüller et al., 2003). The lower altitudinal limit of

167 permafrost (LALP) is clearly lower in the eastern parts of southern Norway (transition zone at

168900 - 1100 m a.s.l. (Heggem et al., 2005; Juliussen and Humlum, 2007), than in the central

169 and western parts (transition zone at 1300 -1550 m a.s.l.; Ødegård et al., 1992; Isaksen et al.,

170 2002; Etzelmüller et al., 2003; Sollid et al., 2003). Both snow conditions and surface material

171 favour a lower permafrost limit in the eastern parts of southern Norway (Farbrot et al., 2011). 
172 In northern Norway, there is a similar gradient of decreasing LALP with the increasingly

173 continental climate away from the coast. In coastal areas permafrost exists above c. $1250 \mathrm{~m}$

174 a.s.1., while in Kilpisjärvi and Abisko, located on the eastern side of the Scandes, permafrost

175 exists down to c. 800 - 850 m a.s.l. (Ridefelt et al., 2008). In inner parts of Finnmark (Farbrot

176 et al., 2013) and northern Finland (Christiansen et al., 2010) permafrost is widespread above

177 treeline (about $400 \mathrm{~m}$ a.s.1.) and common in extensive mires with relatively thick $(>70 \mathrm{~cm})$

178 peat deposits (Seppälä, 1988). Permafrost is also present at local sites with coarse surface

179 material, favouring a cold anomaly, resulting in active rock glaciers down to sea level, e.g. at

180 Nordkinnhalvøya (Lilleøren and Etzelmüller, 2011; Lilleøren, 2016).

181 4. Model description

\section{$182 \quad 4.1 \quad$ Implementation of CryoGRID1}

183 The equilibrium model CryoGRID1, earlier implemented for Norway (Farbrot et al., 2013;

184 Gisnås et al., 2013), is a TTOP-approach (Smith and Riseborough, 1996) providing an

185 estimate for the temperature at the top of permafrost or at the bottom of the seasonal frost

186 layer $(T T O P)$ based on annual freezing $\left(F D D_{a}\right)$ and thawing $\left(T D D_{a}\right)$ degree days in the air:

$$
\text { TTOP }=\left\{\begin{array}{l}
\frac{\left(T D D_{a} * n T * r_{k}+F D D_{a^{*}} n F\right)}{P} \text { for } K_{t} T D D_{s}+K_{f} F D D_{s} \leq \\
\frac{\left(T D D_{a} * n T+\frac{1}{r_{k}} * F D D_{a} * n F\right)}{P} \text { for } K_{t} T D D_{s}+K_{f} F D D_{s} \geq
\end{array}\right.
$$

188 Here, $P$ is the total time period for which $F D D_{a}$ and $T D D_{a}$ are integrated over (i.e. the number

189 of days in one year), while $r_{k}$ is the ratio of ground thermal conductivities in thawed and

190 frozen states. The factors $n T$ and $n F$ are empirical transfer-functions for the surface offset,

191 defined as the offset between air and ground surface temperatures. The transfer-functions

192 include a variety of heat flow attenuation processes in one single variable, such as vegetation, 
193

194

snow cover, soil moisture and topography. The winter $n F$-factor relates the freezing degree days at the ground surface to the air and thus accounts for the effect of the winter snow cover. Likewise the $n T$-factor relates the thawing degree days at the surface (subscript s) to the air (subscript a) and accounts for the surface cover type:

$$
F D D_{s}=n F * F D D_{a} \text { and } T D D_{s}=n T * T D D_{a}
$$

In non-vegetated areas the snow cover and the ground surface temperatures can be highly variable over short distances due to wind drifting of snow (Gisnås et al. 2014). To account for this variation we assume that the distribution of maximum snow depths within a grid cell follows a gamma distribution, following Gisnås et al. (2015). The distribution is defined by the average maximum snow depth $(\mu)$ of the grid cell and here a constant coefficient of variation $(C V)$ of 0.6 is adopted. The probability density function over a range of snow depths (SD) is then given as (Skaugen et al., 2004):

$$
f(S D ; \alpha, \beta)=\frac{1}{\beta^{\alpha} \Gamma(\alpha)} S D^{\alpha-1} e^{-\frac{S D}{\beta}}
$$

with shape parameter $\alpha=C V^{-2}$ and rate parameter $\beta=\mu^{*} C V^{2}$. We run 100 model realizations based on snow depths selected from the probability distribution $f(S D)$.

Corresponding $n$-factors are computed for each realization based on Eq. 4 and 5 below, giving a distribution of TTOP and mean annual ground surface temperatures (MAGST) for each grid cell. Based on the TTOP distribution, the percentage of permafrost, defined as sub-zero $T T O P$, is derived for each grid cell. This percentage is used to classify each grid cell into one of the four distinct permafrost zones reflecting the spatial coverage of permafrost (Brown et al. 1997); no and isolated permafrost $(0-10 \%)$, sporadic permafrost $(10-50 \%)$, discontinuous permafrost $(50-90 \%)$ and continuous permafrost $(90-100 \%)$. Model set up is described in the flow chart in Figure 3. 


\subsection{Parameterization of $n$-factors}

217 The $n$-factors are classified for the following surface cover classes: (1) coniferous forest, (2)

218 broad-leaved forest, transitional woodland and shrub, (3) mire and peat, (4) bedrock and

219 sparsely vegetated area and (5) block field. Variation in observed $n$-factors for forest and

220 shrub is relatively small, with $n T$ typically in the range $0.85-1.1$, and $n F$ in the range $0.3-$

2210.5 (Gisnås et al., 2013). For mires and peat land the $n$-factors in the main model run are

222 parameterized for general mire conditions with a uniform snow cover. One year of data from

223 four temperature loggers over mires with a developed snow cover at Iskoras in Finnmark

224 showed $n T$ and $n F$ values in the range 1.1 to 1.4 and 0.15 to 0.35 , respectively. Based on

225 these data $n T$ and $n F$ at mires without snow drift was given the average values of 1.25 and

2260.26 , respectively (Table 1). However, as a palsa grows, the surface offset changes

227 significantly due to the reduced snow cover and also potentially because of changes in

228 vegetation cover at the top of the palsa. In order to represent the situation at snow free sites in

229 mires and peat land, such as on palsas, a second model run is made with $n$-factors adjusted for

230 "snow free mire conditions". Several years of data from temperature loggers located at the

231 very of top of palsas in Tavvavuoma (8 yrs), northern Sweden (Sannel et al., 2015),

232 Vaisjeaggi (4 yrs) and Kilpisjärvi (2 yrs) in northern Finland, and Iskoras (1 yr), northern

233 Norway, show mean $n T$ and $n F$ values in the range 0.7 to 1.2 , and 0.35 to 0.85 , respectively.

234 The average values of $n T$ and $n F$ are 1.2 and 0.6 , respectively, which is used for this

235 condition in model (Table 1).

236 Observed variations in $n T$ and $n F$ within the open non-vegetated areas are comparably large,

237 with values typically in the range $0.4-1.2$ for $n T$ and $0.0-1.0$ for $n F$. The large range is

238 related to the high impact and high spatial variability of snow depths (Gisnås et al., 2014).

239 While $n F$ accounts for the insulation from snow due to low thermal conductivity, $n T$

240 indirectly compensates for the shorter season of thawing degree days at the ground surface in 
areas with a thick snow cover. Relationships between $n$-factors for open areas and maximum snow depths $(S D)$ are established based on air and ground temperature observations, together with snow depth observations at the end of accumulation season at nearly 100 sites in southern Norway, presented in Gisnås et al. (2015) as:

$$
\begin{aligned}
& n F=-0.16 * \ln (S D)+0.22 \\
& n T=-0.14 * S D+1.1
\end{aligned}
$$

The thermal conductivities of the different surficial materials, excluding mires, are derived from 28 000-point measurements of petrophysical data such as bedrock density and thermal conductivity provided by the Geological Survey of Norway (NGU) (Olesen et al., 2010), along with thermal properties used in other models (GIPL 1.0 - Geophysical Institute Permafrost Laboratory) (Table 2). A comprehensive overview is given in Gisnås et al. (2013). For mires, $r_{k}$ is increased to 0.75 , based on a model fit over borehole temperatures measured in peat plateaus in Tavvavuoma (Sannel et al., 2015) and Vaisjeaggi.

\section{Data and field observations}

\subsection{Climate forcing data}

The Nordic Gridded Climate Data set (NGCD) of daily gridded air temperature and precipitation data at $1 \mathrm{~km}^{2}$ resolution for the period $1981-2010$ is provided by the Norwegian Meteorological Institute. NGCD is developed within the Nordic Framework for Climate Services (http://blog.fmi.fi/nordmet/node/100), based on the Norwegian Climate 
Database in addition to the European Climate Assessment Dataset (ECA\&D, Klein Tank et $a l .$, 2002). Original non-homogenized time series were used. The number of stations used for

264 the interpolation varies with time due to data availability. In more than $80 \%$ of the time steps

265 the interpolation is based on data from more than 1100 precipitation stations and 371

266 temperature stations. These are distributed over the three countries with approximately $25 \%$

267 of the stations in each of Norway and Finland and 50\% in Sweden. The station distribution is

268 rather stable in the time period considered. In NGCD, the operational choices we've made

269 were to use all the available observations for each timestep and to keep the statistical

270 interpolation settings fixed in time such that its filtering and smoothing properties are also

271 constant in time. As a result, any significant variation in time of the NGCD statistics should

272 be attributed to an actual modification in the underlying climatological probability density

273 function. However, as pointed out in Masson and Frei (2016), the variations in the station

274 network have an impact in the estimation of long-term trends from observational gridded

275 datasets and further investigations are needed to accurately assess this impact on the NGCD.

276 The interpolation of the NGCD gridded data set is based on two original implementations of

277 the well-established statistical interpolation method called Optimal Interpolation (OI; Gandin

278 (1965)). The goal of OI is to provide the best (i.e. minimum error variance for the final

279 prediction), linear, unbiased estimate of the unknown meteorological field. Two distinct OI-

280 based schemes are developed for temperature and precipitation because of the different

281 statistical properties of the two meteorological variables. Nonetheless, for both variables the

282 spatial interpolation relies on the scale-separation concept, which is based on the idea that the

283 final predicted value is a combination of large scale and local scale effects. As a first step, we

284 aim at estimating the contribution of atmospheric processes operating on scales greater than

285 the local station density (i.e. large scale), thus influencing dozens of stations. Then we include

286 the effects of atmospheric processes acting at the local scale, as simultaneously observed by a 
few stations over an area significantly smaller than the one used in the previous step. The

288 small-scale component of an observed value that the spatial interpolation scheme is unable to resolve constitutes the so-called representativity error (Lussana et al., 2010), which is part of the observation error in OI. For example, very local responses to mesoscale dynamics may

291 affect just one or very few observations, thus determining large uncertainties in the final 292 prediction.

293 An empirical Bayesian approach has been adopted for the implementation of the spatial

294 interpolation scheme, where a priori information on the grid is combined with point 295 observations. The a priori information is estimated from the observations and serves as a representation on the large scale. Given the actual station distribution, it is expected that the

297 NGCD would properly resolve atmospheric processes from the synoptic down to the meso298 beta scale (Orlanski, 1975; Thunis and Bornstein, 1996).

299 The first step for spatial interpolation for the daily mean temperature is the estimation of a 300 large-scale temperature field, both on the grid and at station locations, by means of a non301 linear de-trending procedure. Similar procedures are described in Uboldi et al. (2008) and Frei 302 (2014). The large-scale field information can represent several regional vertical temperature 303 profiles. This allows for both ground-based inversions as well as temporal changes of the 304 vertical profiles at every time step, depending on the actual atmospheric conditions. In the 305 second step, the large-scale background field is modified on a local basis by a few 306 neighbouring stations employing an OI as described in Uboldi et al. (2008). In this way the 307 best linear unbiased estimate of the unknown true temperature state is achieved. The 308 procedure used to set the de-correlation scale values is based on a trade-off between the 309 necessity to incorporate the added value of the local scale information into as many large310 scale (background field) grid points as possible, and the need to keep a substantial distinction 311 between large and local scale effects. Several tests were conducted with different de- 
correlation scale values in order to optimize the leave-one-out cross-validation score (Uboldi

313 et al., 2008). Based on these test the values of $60 \mathrm{~km}$ and $600 \mathrm{~m}$ were found to be optimal for

314 the horizontal and vertical directions, respectively. To deal with the presence of gross

315 measurement errors in the temperature observations, a spatial consistency test is included in

316 the statistical interpolation, as described in Lussana et al. (2010).

317 In the case of daily accumulated precipitation, the spatial interpolation begins with the

318 identification on the grid of simultaneous observed areas of precipitation (i.e. precipitation

319 events), followed by the statistical interpolation on each area considered independent from the

320 others. The statistical properties of the field are allowed to change between different observed

321 areas of precipitation. Eventually, the analysis field is a composition of several precipitation

322 events, which are considered individually. In each individual area of observed precipitation,

323 the statistical interpolation is based on a multi-scale separation concept through iteration from

324 the large-scale (up to the synoptic scale, depending on the event extension) down to the finer

325 scale, predefined as $10 \mathrm{~km}$. In each iteration the statistical interpolation scheme is based on

326 OI, and the parameters for the spatial covariance are optimized independently for each event

327 by minimizing the deviations between leave-one-out cross-validated analysis and observed 328 values.

329 The snow depth data was produced from the air temperature and precipitation data by

330 employing the SeNorge snow model v.1.1.1., described in Saloranta (2012). Precipitation at 331 temperatures below $0.5^{\circ} \mathrm{C}$ is considered as snow, and snow water equivalents are calculated 332 directly from precipitation and temperature data. Snow depths are derived from snow water 333 equivalents using an algorithm that takes into account snow accumulation, temperature during 334 snowfall, compaction and snow melt. Average mean annual air temperature and maximum 335 snow depths over the 30-year period 1981-2010 are shown in Figure 1. 


\subsection{Surface cover and soil data}

$337 n$-factors were assigned to groups of surface cover classes in the newest CORINE dataset, 338 CLC2012 (Aune-Lundberg and Strand, 2010). Sediment and bedrock maps are provided by 339 the Geological Surveys of Finland, Sweden and Norway. The maps are unified into one 340 classification for $r_{k}$, following CryoGRID1 (Table 2).

\section{$341 \quad 5.3 \quad$ Field observations used for evaluation}

342 The modelled TTOP results are evaluated against 25 boreholes shown as blue and yellow dots

343 in Figure 2 (Isaksen et al., 2001; Christiansen et al., 2010; Farbrot et al., 2011), all

344 incorporated in the GTN-P database (Biskaborn et al., 2015). Modelled MAGST is evaluated

345 with an extensive dataset of temperatures from more than 100 ground surface temperature

346 (GST)-loggers distributed over Norway (Figure 2). For evaluation with temperature data the

347 model is run for the hydrological year corresponding to the ground or ground surface

348 temperature observations.

349 The overall modelled distribution of permafrost is evaluated towards maps of palsa

350 distribution derived from aerial photographs from Norway (Borge et al., 2016), Sweden

351 (Backe, 2014) and Finland (Metsähallitus, 2002) (red dots in Figure 2). The Swedish maps are

352 in grid squares of $100 \mathrm{~m} \times 100 \mathrm{~m}$, where the percentage of palsas and water related to palsas

353 were specified. Furthermore, the modelled permafrost zonation is evaluated against

354 permafrost probability maps derived from BTS-surveys at Kilpisjärvi (Majava, 2014), Abisko

355 (Ridefelt et al., 2008), Dovrefjell and Juvvasshøe (Isaksen et al., 2002), and Elgåhogna and

356 Sølen (Heggem et al., 2005) (outlined in purple in Figure 2). 


\section{Results and discussion}

359

360

361

362

363

364

365

366

\subsection{Modelled permafrost distribution in the Scandinavian Peninsula}

The model results indicate a permafrost area in Scandinavia of c. $23400 \mathrm{~km}^{2}$ in equilibrium with the 1981-2010 climate, when snow free mires are excluded (Figure 4 and Figure S1).

The areas modelled to have permafrost are exclusively in non-forested areas, of which $21 \%$ of the total distribution is found to be in areas classified as block fields. $56 \%$ is located in Norway, $35 \%$ in Sweden, and $9 \%$ in Finland. In total, the area with a grid cell percentage of permafrost above $10 \%$ is c. $62600 \mathrm{~km}^{2}$, whereof $2 \%$ of the area is classified as continuous permafrost (> $90 \%), 20 \%$ discontinuous $(50-90 \%)$ and $78 \%$ is sporadic $(10-50 \%)$.

In the "snow free mire" model run c. $5570 \mathrm{~km}^{2}$ are modelled as potential permafrost. Norway, Finland and Sweden holds $51 \%, 38 \%$ and $11 \%$ of these areas, respectively. In reality, permafrost can be found only in sites with favourable local conditions for permafrost development (e.g. thin snow cover, $>70 \mathrm{~cm}$ peat deposits and no regular flooding) (Seppälä, 1988; Luoto and Seppälä, 2002; Seppälä, 2011).

The modelled gradient in LALP with distance from the coast is in accordance with earlier observations. In southern Norway the modelled distribution of discontinuous and sporadic LALP decreases from $1750 \mathrm{~m}$ a.s.l. and $1450 \mathrm{~m}$ a.s.l. in the west to $1350 \mathrm{~m}$ a.s.l. and $1050 \mathrm{~m}$ a.s.l. in the east, respectively (Figure 5, left). In northern Norway it decreases from $1400 \mathrm{~m}$ a.s.l. and $1200 \mathrm{~m}$ a.s.l. down to $350 \mathrm{~m}$ a.s.l. and $150 \mathrm{~m}$ a.s.l. in the eastern parts, respectively (Figure 5, left). The gradient is very low east of the Scandes in the north, where the LALP for discontinuous permafrost stabilizes at around $400 \mathrm{~m}$ a.s.l. through Finnmark and northern Finland. This elevation corresponds to the upper limit of birch forest in this area. The model results indicate occurrences of sporadic permafrost all the way out to the coast in northern 
Norway, while in southern Norway there is no permafrost modelled closer than $150 \mathrm{~km}$ from

382 the coast line (Figure 5, left).

383 There is also a strong latitudinal gradient in the LALP. Sporadic permafrost is present as far 384 south as $60^{\circ} \mathrm{N}$, here above $1500 \mathrm{~m}$ a.s.l. The LALP for discontinuous permafrost is 1650 at $38561^{\circ} \mathrm{N}$. From $64{ }^{\circ} \mathrm{N}$ to $70{ }^{\circ} \mathrm{N}$ the LALP decreases gradually down to $150 \mathrm{~m}$ a.s.l. for sporadic 386 and $350 \mathrm{~m}$ a.s.l. for discontinuous permafrost, respectively. The LALP for sporadic 387 permafrost increases again in the northernmost maritime areas of northern Norway.

388 The extent of the modelled distribution of permafrost follows the general distribution of 389 permafrost in the IPA map (Brown et al., 1997). However, the correspondence is higher in the 390 northern than the southern parts of the Scandinavian Peninsula (Figure 4). At the time that the 391 IPA map was derived, the permafrost research in Scandinavia was focused in the 392 northernmost areas, which might explain this pattern. The main difference between the maps 393 is the level of detail. While the new permafrost map presented here has a raster resolution of 1 $394 \mathrm{~km}^{2}$, the IPA map is made in a mapping scale of 1:10,000,000. Assuming details down to 1 $395 \mathrm{~mm}$ are visible in the IPA map, this corresponds to $10 \mathrm{~km}$ on the ground. The extent of the 396 permafrost area outlined by the IPA map coincides well with the outer limits of permafrost in 397 the new permafrost map. However, with the finer resolution we obtain a much higher level of 398 detail of the permafrost distribution, in relation to the variation in topography and surface 399 cover. This is reflected in the large area classified as lowland permafrost in Sweden, where 400 only smaller occurrences of permafrost are present in the new map. Still, there is a very good 401 accordance in the outer limits of permafrost occurrences between the maps.

402 In the IPA map $175000 \mathrm{~km}^{2}$ are classified as highland permafrost and $80000 \mathrm{~km}^{2}$ as lowland 403 permafrost in the Scandinavian Peninsula. Because the new permafrost map does not separate 404 between highland and lowland permafrost, but treat all permafrost areas except mires the 
same way, the areal numbers are not directly comparable. However, the total area of highland permafrost in the IPA map is almost 8 times as large as the total area of permafrost, mires excluded, in the new permafrost map. The total permafrost area including all types of permafrost (highland and lowland in the IPA map, and including mires in the new map) are almost 9 times larger in the IPA map than in the new permafrost map. The total permafrost area in the IPA map is distributed between the countries with $53 \%, 34 \%$ and $13 \%$ in Norway, Sweden and Finland, respectively. This is in good accordance with the distribution in the new permafrost map.

\subsection{Validation of the NGCD temperature data}

The network of meteorological stations in Scandinavia follows the density of the population pattern and infrastructure. Consequently, the northern as well as the more mountainous areas feature a much more sporadic network of observations. This influences the quality of the interpolated meteorological data. Permafrost is restricted to areas with a very sparse station density. A validation with daily air temperatures measured at six meteorological stations located in permafrost areas are performed (Figure 6): Storkløftfjellet located at the top of the plateau at Varangerhalvøya $\left(70.54^{\circ} \mathrm{N}, 29.34^{\circ} \mathrm{E}, 486 \mathrm{~m}\right.$ a.s.1.), Iskoras $\left(69.30^{\circ} \mathrm{N}, 25.35^{\circ} \mathrm{E}, 585\right.$ m a.s.1.), Vaisjeaggi $\left(69.82^{\circ} \mathrm{N}, 27.17^{\circ} \mathrm{E}, 290 \mathrm{~m}\right.$ a.s.1. $)$, Abisko Research Station $\left(67.92^{\circ} \mathrm{N}\right.$, $18.87^{\circ} \mathrm{E}, 355 \mathrm{~m}$ a.s.1.), Tarfalaryggen $\left(67.92^{\circ} \mathrm{N}, 18.63^{\circ} \mathrm{E}, 1550 \mathrm{~m}\right.$ a.s.1.) and Juvvasshøe $\left(61.68^{\circ} \mathrm{N}, 8.38^{\circ} \mathrm{E}, 1894 \mathrm{~m}\right.$ a.s.1.) (see all locations in Figure 2). Temperature observations from the Abisko and Juvvasshøe sites are included in the meteorological station network of the NGCD dataset, and the modelled temperatures at these two stations have therefore a significantly lower bias compared to the others, which are not included. In other words, given that Abisko and Juvvasshøe observations enter the spatial interpolation scheme for these sites we are evaluating the uncertainty due to the representativity error component of the 
observation (see Sect. 5.1). For the other sites we are evaluating the uncertainty is due to the

430 prediction error.

431 The impact of the representativity error on the uncertainty in predictions is in general higher 432 in winter than in summer, as can be seen in Figure 6 for Abisko and Juvvasshøe. However, it 433 is quite evident that the agreement between modelled and observed values is better in 434 Juvvasshøe than in Abisko, both in terms of bias and dispersion around the perfect prediction.

435 The reason is in part due to the close relation between station density and representativity 436 error: for areas characterized by a denser station network, as in southern Norway where 437 Juvvasshøe is located, the uncertainties due to the representativity error are smaller than for 438 areas with a sparser station network, as for the Abisko area in northern Sweden. In general, in 439 OI, as in any Bayesian spatial interpolation scheme, the impact of representativity error on the 440 prediction uncertainties can be reduced by improving the quality of the a priori information, 441 for example by using output fields from high-resolution numerical models.

442 The distribution of summer (May - September) temperatures (red) are relatively well 443 represented at all sites, with coefficients of determination $\left(R^{2}\right)$ from 0.84 to 0.99 (Figure 6).

444 The stations at Varangerhalvøya and Tarfalaryggen still feature warm biases of $1.6{ }^{\circ} \mathrm{C}$ and 1.1 $445{ }^{\circ} \mathrm{C}$, respectively. The representations of winter (October - April) temperatures (blue) are less 446 accurate, with $R^{2}$ of 0.8 at Varangerhalvøya and Iskoras, and as low as 0.6 at Tarfalaryggen. 447 All stations except for the one at Varangerhalvøya feature cold biases during the winter 448 season, as large as $-2{ }^{\circ} \mathrm{C}$ for Iskoras and Vaisjeaggi. These two stations are located at each 449 side of the border in eastern Finnmark (Figure 2), where strong temperature inversions 450 dominate during winter. The lack of stations at higher elevations prevents the inversions from 451 being captured by the interpolation routine. The station Storkløftfjellet at Varangerhalvøya is $4521.5^{\circ} \mathrm{C}$ too warm in both summer and winter. The northernmost part of Finnmark has in 453 general very few stations, all located along the coast in maritime settings. Because of the lack 
of stations at higher elevations, the maritime climate highly influences the interpolation at the top of Varangerhalvøya, but also higher elevated areas in large parts of northern Finnmark.

\subsection{Evaluation of the permafrost model}

The model results reproduce the measured mean annual ground temperature $(M A G T)$ at the top of permafrost in boreholes within the range of the grid cell for $94 \%$ of the observations (Figure 7). All observations are within $\pm 2{ }^{\circ} \mathrm{C}$ of the average temperature of the grid cell, with an overall $R M S E$ of $0.75^{\circ} \mathrm{C}$. The ground temperatures for the coldest boreholes are generally about $1{ }^{\circ} \mathrm{C}$ lower than the average modelled temperature. This is because they are all located at very exposed and snow free sites, and are representative for the colder end of the modelled distribution, and not the average.

The distribution of mountain permafrost corresponds well to all available permafrost probabilities derived from BTS-surveys (Figure 8). The agreement is particularly high in the Juvvasshøe area in central Jotunheimen, but also at Abisko and Dovrefjell the limits for both $50 \%$ (black contour line and purple colour) and the $80 \%$ (red contour line and blue colour) probability of permafrost are well represented (Figure 8). At Dovrefjell sporadic permafrost are modelled down to about c. $1350 \mathrm{~m}$ a.s.1., which is in accordance with observations indicating permafrost at bare blown areas down to this elevation (Sollid et al., 2003). The model shows too little permafrost compared to the BTS-maps in Kilpisjärvi and at the two sites in southeast Norway; Elgåhogna and Sølen. In southeast Norway the temperature forcing has a warm bias, resulting in underestimation of permafrost in this area. From visual inspection, the distribution of permafrost is in good accordance with observations for most of Scandinavia. However, the model results show no permafrost in the northernmost parts of Finnmark, including Varangerhalvøya and Norkinnhalvøya. Permafrost has been documented from the higher parts of the plateau at Varangerhalvøya (Isaksen et al., 2008; Farbrot et al., 
2013), while the permafrost model show sporadic to no permafrost in this area. This is related to the warm bias in the temperature forcing data for this area, seen in the validation at Storkløftfjellet (Sect. 6.2 and Figure 6)

\subsection{Palsa distribution in Scandinavia}

For the evaluation of the modelled permafrost in "snow free mires", the national maps of palsa observations were resampled to $250 \mathrm{~m}$ resolution with all grid cells containing an area mapped as palsa included. At this resolution the total areal distribution of palsas is c. 1510 $\mathrm{km}^{2}$, with $55 \%$ in Norway, $32 \%$ in Sweden and $13 \%$ in Finland. The palsas are mainly located at elevations below 1000 m a.s.1., with almost $60 \%$ at elevations between 350 and 500 meters a.s.l. (Figure 9). The amount of annual FDDs are mainly lower than -1500 ${ }^{\circ} \mathrm{C}^{*}$ days, with more than $60 \%$ of the locations colder than $-2000{ }^{\circ} \mathrm{C}^{*}$ days. This is in accordance with the findings by Aalto and Luoto (2014). Annual TDDs for most palsa areas are around $1000{ }^{\circ} \mathrm{C}^{*}$ days, while maximum snow depths are below 0.6 meters. This pattern is fairly well reproduced by the model (Figure 9).

However, the modelled potential permafrost area at snow free mires covers as much as c. $5570 \mathrm{~km}^{2}$, with $51 \%$ of the area in Norway, $11 \%$ in Sweden and 38\% in Finland. Only $15 \%$ of this area corresponds to grid cells with observed palsas, and the total modelled area significantly exceeds the mapped palsa distribution. The main reason for this is that only $60 \%$ of the observed palsas are located in grid cells classified as "mire or peatland" in the CLC2012 land use map with 250 m resolution. In most cases there are grid cells classified as mires in the very near vicinity of palsas. However, in a few areas such as in the southernmost palsa area in western Sweden, the palsas are often classified as sparsely vegetated area. Another main reason for this overestimation is that the formation of a palsa depends on a range of local conditions, and even though the climate is cold enough to allow for a 
sustainable palsa, there may not be any palsa formation because of the local wind exposure

503 and related snow drifting, peat layer, soil moisture or drainage patterns (Seppälä, 1988). A

504 few years of favourable conditions can initiate the formation of a palsa that will remain in 505 much less favourable conditions than when it was first established (Seppälä, 2011). The 506 equilibrium model used in the new permafrost map can only provide an estimate of areas 507 where already formed palsas would be likely to exist in equilibrium with the average climatic 508 condition of the period 1981-2010. Palsas are therefore not present on all mires that are 509 modelled to potentially have a palsa. In addition, permafrost in mires and peatland may be 510 present even though they are not included in the palsa map. These maps, which are made from 511 aerial photographs, do only include palsas that are visible in the aerial photographs. It should 512 be noted that permafrost can also be present in peaty hummocks smaller than palsas (e.g. 513 Luoto and Seppälä, 2002).

514 In some areas there are also biases introduced by inaccuracies in the map of mires and the 515 climate forcing data. Out of the $60 \%$ of the grid cells with observed palsas correctly classified 516 as mire, $90 \%$ are modelled as permafrost in the model run. The remaining $10 \%$ are located in 517 the northern parts of Finnmark, and in valleys close to Abisko. The underestimation in the 518 northern parts of Finnmark is explained by the observed warm bias in the gridded temperature 519 data at Varangerhalvøya (discussed in Section 6.2). The temperature validation to the 520 meteorological station at Abisko shows very good correlation (Figure 6). However, in 521 Katterjokk ( $25 \mathrm{~km}$ west of Abisko) a palsa mire has degraded, and since the year 2000 the 522 permafrost has largely disappeared (Åkerman and Johansson, 2008). In Stordalen ( 10 km 523 east of Abisko) palsas have degraded between 1970 and 2000 as a result of permafrost thaw 524 (Johansson et al., 2006). Because the model shows the distribution of potential palsa areas in 525 an equilibrium situation, the palsas might correctly be represented as not having permafrost in 526 equilibrium with the average climate over 1981 - 2010. In addition, local inversion 
phenomena in the surrounding valleys to Abisko could cause very cold winter conditions, which might not be well represented in the temperature data due to few meteorological stations located in this area.

The distribution map of potential palsa areas provides a good indication of areas where we can expect to find permafrost in mire environments (i.e. palsas and other permanently frozen peat hummocks). This map is also useful to detect areas where palsas are likely to thaw in the near future. The exact distribution is beyond the limitations of what an equilibrium model can represent, and would require a better representation of site-specific input parameters and the distribution of mires.

\subsection{Response of permafrost to the climate change over the period 1981-2010}

Significant increases in degree days are seen in the NGCD dataset over the period from 1980 to 2010. Time series are extracted from the dataset for four permafrost field sites Vaisjeaggi, Abisko, Tarfalaryggen and Juvvasshøe (Figure 2). All stations are validated with observations from the last few years of the period in Figure 6. The time series are shown as running means of annual thawing (TDD) and freezing (FDD) degree days in the air (Figure 10, a and b), and as annual maximum snow depths (Figure 10, c). The average value over each decade is drawn as a line.

At the two palsa mire sites, Vaisjeaggi and Abisko, the NGCD dataset shows an increase in annual TDD of $200{ }^{\circ} \mathrm{C}^{*}$ days from the second to the third decade. The increase in TDD at the two high-mountain sites, Tarfalaryggen and Juvvasshøe, is less significant, while FDD increase with almost $1000{ }^{\circ} \mathrm{C}^{*}$ days at Tarfalaryggen and $500{ }^{\circ} \mathrm{C}^{*}$ days at Juvvasshøe. The inter-annual variation in maximum snow depth is high at all sites, but a general decrease in snow depth can be seen towards the end of the period. The first two decades are similar, and 
there is even a slight increase in snow depth from the first to the second decade at

551 Tarfalaryggen and Vaisjeaggi (Figure 10, c).

552 The response in ground temperatures to this climatic change is demonstrated by comparing

553 the potential permafrost distribution for three time slices (Figure 11). For this analysis,

554 permafrost in snow free mires is not included. The total permafrost area in equilibrium with

555 the climate of the first period is $36800 \mathrm{~km}^{2}$. The modelled decrease to the second decade

556 given a new equilibrium is about $36 \%$, while to the third the total permafrost area is reduced

557 by $64 \%$. The relative reduction for each period is similar for all three countries. A

558 particularly large decrease is seen in the areas of discontinuous lowland permafrost in

559 Finland, northern Sweden and the eastern parts of Finnmark (Figure 11, b). This clearly

560 demonstrates that large areas with modelled occurrences of permafrost during the period

561 1980-1990, would not have permafrost in equilibrium with climate conditions similar to the

562 period 2000-2010 (cf. Kukkonen and Šafanda, 2001).

563 The decrease in potential palsa areas is also significant, with a distribution restricted to

564 Finnmark, Tavvavuoma and the area around Kilpisjärvi for the equilibrium situation with the

565 average climate over 2001 - 2010 (Figure 11Error! Reference source not found., d). In

566 southern Norway, where the distribution of palsas is more marginal, an increase in elevation

567 is seen from the first to the second period, while there are hardly any modelled potential palsa

568 areas in the third time slice. However, palsas can still be found within the areas, but modelled

569 as degraded, because palsas are slow systems with a significant time lag, and can remain in

570 warmer climates (Seppälä, 2011). However, this indicates that palsas within these areas are

571 vulnerable to degradation if the climate of the $2001-2010$ period would continue, which is in

572 accordance with the projected degradation of palsa mires by Fronzek et al. (2006) and Aalto

573 et al. (2014). 
575 The main goal of this paper is to provide a first detailed baseline for permafrost distribution in 576 Scandinavia. Compared to the more generalized IPA map this map provides a similar, but 577 much more detailed picture of the distribution of mountain and lowland permafrost. The 578 model is forced with climate data produced from operational meteorological stations, 579 parameterized and evaluated with the use of all available field observations, and thoroughly 580 validated by a large collaborating permafrost research community in Scandinavia. By 581 combining simple modelling, a large ensemble of observations (for parameter calibration) and 582 qualitative validation, the first permafrost map for the Scandinavian Peninsula provides a 583 higher level of detail and stronger confidence in the model results than the larger scale IPA 584 permafrost map (Brown et al., 1997) for this region. For Scandinavia this map will certainly 585 serve as a baseline model for validation of GCM or RCM-based permafrost evaluation in the 586 future, along with already published large-scale attempts as published by Gruber (2012) and 587 Westermann et al. (2015).

588 The implementation of a sub-grid variability of snow depths enables computation of the 589 percentage of $M A G T<0{ }^{\circ} \mathrm{C}$ in each grid cell. This allows for a representation of the 590 permafrost extent with a gradual zonation. It enables sensitivity studies with increased snow 591 depths or air temperatures, and because the full range of ground temperatures is represented, it 592 will give a more realistic response to changes in the climate forcing. The map therefore 593 provides a more dynamic aspect than the static IPA map, even one must be cautious to use 594 such type of models for permafrost prediction under a changing climate..

595 Furthermore, the combination of climate, snow and soil parameters opens for local 596 estimations of e.g. freezing depth and active layer thickness within a grid cell by employing 597 semi-empirical relations like the Stefan solution (e.g. Nelson and Outcalt, 1987). The 
resolution is too coarse for detailed local assessments such as permafrost temperature

599 distributions in steep slopes. However, the resolution and zonation is sufficient to assess in 600 which areas problems related to frozen ground can be expected to be found. Thereby it may 601 also serve to provide useful estimates of boundary conditions necessary for physically-based 602 modelling accounting for active layer dynamics (e.g. Frampton and Destouni, 2015).

603 In the IPA map permafrost, palsas were not represented separately in Finland, Norway and 604 Sweden, but instead incorporated in the permafrost class "Sporadic to isolated patches of 605 lowland permafrost". Some perennial frost mounds were identified, however, in other 606 permafrost regions. Still, compared to the observed palsa distribution, there is a large 607 discrepancy in the level of detail between the IPA map and the permafrost map for the 608 Scandinavian Peninsula. This new permafrost map shows clear improvements in the 609 representation of the areas of potential palsas and other permafrost features by using a fine 610 representation of the distribution of peat and mire areas, combined with air temperatures and 611 snow at $1 \mathrm{~km}^{2}$ resolution. In this way we are able to model the distribution of mires with 612 potential for permafrost under favourable local conditions.

613 The spatial extent of the mire areas with potential permafrost fit relatively well with the extent 614 of palsas. However, while the model projects permafrost in all mires of an area with a climate 615 cold enough for palsa formation, palsas are only present at sporadic locations in the mires.

616 Because of the highly sporadic nature and slow climatic response of palsas, it is difficult to 617 obtain a precise representation of palsa features in regional models. The spatial variation is 618 very high for a range of variables, including soil moisture and drainage patterns, snow 619 distribution, and thickness and thermal properties of the peat layer (Seppälä, 1988; 2011). To 620 sufficiently model the transient evolution of a palsa, a detailed description of all these 621 parameters and related processes must be included (e.g. An and Allard, 1995; Kujala et al., 622 2008). This is a challenging task on a local scale, and not possible in such regional models. 


\section{Conclusions}

624 In this paper a baseline permafrost map for Norway, Sweden and Finland is presented. The

625 map is thoroughly validated and consistent with field thermal and landform observations.

626 Borehole observations are well within $\pm 2{ }^{\circ} \mathrm{C}$ of the average modelled top permafrost

627 temperature in the grid cell with an overall $R M S E$ of $0.75{ }^{\circ} \mathrm{C}$. Qualitative evaluation of the

628 permafrost zonation indicates that the general accuracy in the lower altitudinal limit of

629 permafrost is within 100 meters, and that the distribution fits well against BTS-mappings.

630 Based on these more detailed descriptions of the permafrost distribution of the Scandinavian

631 Peninsula, the following main conclusions are obtained:

632 - C. $23400 \mathrm{~km}^{2}$ of the land area is underlain by permafrost (palsas excluded) in 633 equilibrium with the $1981-2010$ climate. About $56 \%$ of the permafrost area is within $634 \quad$ Norway, $35 \%$ in Sweden, and $9 \%$ in Finland.

635 - The distribution of permafrost (mires excluded) is $60 \%$ less in equilibrium with the 636 climate over the period $2000-2010$ than with the climate of $1981-1990$. This indicates 637 that large areas are thawing with possible degradation in the lowland permafrost in 638 northeast Scandinavia, as well as degradation of sporadic permafrost in the coastal 639 mountain areas in Troms and Finnmark.

$640 \quad-\quad$ The mapped palsas cover c. $1510 \mathrm{~km}^{2} ; 55 \%$ in Norway, $32 \%$ in Sweden, and $13 \%$ in 641 Finland. According to the model results, large parts of the mapped palsas are located in 642 areas with significant warming of the permafrost during the $1981-2010$ period. This 643 indicates that the palsas are not in equilibrium with the climate of the last decade, due 644 to their slow climatic response.

645 - The modelled permafrost extent coincides well with the outer boundaries of the 646 permafrost in the IPA map. However, because of the much higher level of detail in the 

map.

\section{Acknowledgements}

650 This work is done as part of the collaboration network PermaNordnet (Nordforsk No. 43082),

651 funded by NordForsk (Nordic Council of Ministers), the RCN-funded CRYOMET project

652 (CRYOMET - 214465) and the Department of Geosciences, University of Oslo, Norway.

653 Compilation of monitoring data from Tavvavuoma was supported by the Swedish Research

654 Council for Environment, Agricultural Sciences and Spatial Planning (214-2014-562), the

655 Bolin Centre for Climate Research and the Nordic Centre of Excellence DEFROST project.

656 We also acknowledge the support from the Academy of Finland (project number 285040).

657 Gøran Alm at Stockholm University provided the sediment maps for Sweden, and Jon

658 Engström at the Geological Survey of Finland greatly contributed with geological data from

659 Finland. Amund Frogner Borge, University of Oslo, provided the digital version of the palsa

660 map of northern Norway, and Susanne Backe at the County Administrative Board in

661 Norrbotten provided the digital version of the palsa map of Sweden. We gratefully

662 acknowledge the support of all mentioned individuals and institutions.

\section{$6639 . \quad$ Supporting Information}

664 Figure S1: The new permafrost map for Norway, Sweden and Finland classified in continuous

665 (blue), discontinuous (purple) and sporadic (pink) permafrost zones. Areas with isolated

666 patches of permafrost in mires are shown in brown colour. 
Aalto, J., and M. Luoto. 2014. Integrating climate and local factors for geomorphological distribution models, Earth Surf. Process. Landf., 39: 1729-1740, DOI:10.1002/esp.3554.

Aalto, J., A. Venäläinen, R. K. Heikkinen, and M. Luoto. 2014. Potential for extreme loss in high-latitude Earth surface processes due to climate change, Geophysical Research Letters, 41: 3914-3924, DOI:10.1002/2014GL060095.

Åkerman, H. J., and M. Johansson. 2008. Thawing permafrost and thicker active layers in sub-Arctic Sweden, Permafrost and Periglacial Processes, 19: 279-292.

An, W., and M. Allard. 1995. A mathematical approach to modelling palsa formation: Insights on processes and growth conditions, Cold Regions Science and Technology, 23: 231-244, DOI:http://dx.doi.org/10.1016/0165-232X(94)00015-P.

Aune-Lundberg, L., and G.-H. Strand. 2010. CORINE Land Cover 2006. The Norwegian CLC2006 project, 14p pp, Report from the Norwegian Forest and Landscape Institute: $11 / 10$.

Backe, S. 2014. Kartering av Sveriges palsmyrar, ISSN 0283-9636 pp, Länsstyrelsen i Norrbotten.

Ballantyne, C. K. 2010. A general model of autochthonous blockfield evolution, Permafrost and Periglacial Processes, 21: 289-300, DOI:10.1002/ppp.700.

Biskaborn, B. K., J.-P. Lanckman, H. Lantuit, K. Elger, S. Dmitry, C. William, and R. Vladimir. 2015. The new database of the Global Terrestrial Network for Permafrost (GTN-P), Earth System Science Data, 7: 245-259, DOI:10.5194/essd-7-245-2015.

Borge, A. F., S. Westermann, I. Solheim, and B. Etzelmüller. 2016. Strong degradation of palsas and peat plateaus in northern Norway during the last 60 years, The Cryosphere Discuss., 2016: 1-31, DOI:10.5194/tc-2016-12.

Brown, J., O. J. J. Ferrians, J. A. Heginbottom, and E. S. Melnikov. 1997. International Permafrost Association Circum-Arctic Map of Permafrost and Ground Ice Conditions., U.S. Geological Survey.

Christiansen, H. H., B. Etzelmüller, K. Isaksen, H. Juliussen, H. Farbrot, O. Humlum, M. Johansson, T. Ingeman-Nielsen, L. Kristensen, J. Hjort, P. Holmlund, A. B. K. Sannel, C. Sigsgaard, H. J. Åkerman, N. Foged, L. H. Blikra, M. A. Pernosky, and R. S. Ødegård. 2010. The thermal state of permafrost in the nordic area during the international polar year 2007-2009, Permafrost and Periglacial Processes, 21: 156181, DOI:10.1002/ppp.687.

Elberling, B., H. H. Christiansen, and B. U. Hansen. 2010. High nitrous oxide production from thawing permafrost, Nature geoscience, 3: 332-335.

Etzelmüller, B., I. Berthling, and J. L. Sollid. 2003. Aspects and concepts on the geomorphological significance of Holocene permafrost in southern Norway, Geomorphology, 52: 87-104, DOI:10.1016/s0169-555x(02)00250-7.

Farbrot, H., T. F. Hipp, B. Etzelmüller, K. Isaksen, R. S. Ødegård, T. V. Schuler, and O. Humlum. 2011. Air and Ground Temperature Variations Observed along Elevation and Continentality Gradients in Southern Norway, Permafrost and Periglacial Processes, 22: 343-360, DOI:10.1002/ppp.733.

Farbrot, H., K. Isaksen, B. Etzelmüller, and K. Gisnås. 2013. Ground Thermal Regime and Permafrost Distribution under a Changing Climate in Northern Norway, Permafrost and Periglacial Processes, 24: 20-38, DOI:10.1002/ppp.1763.

Frampton, A., and G. Destouni. 2015. Impact of degrading permafrost on subsurface solute transport pathways and travel times, Water Resources Research, 51: 7680-7701, DOI:10.1002/2014WR016689. 
Frei, C. 2014. Interpolation of temperature in a mountainous region using nonlinear profiles and non-Euclidean distances, International Journal of Climatology, 34: 1585-1605, DOI:10.1002/joc.3786.

French, H. 2007. The Periglacial Environment, 3. ed., 458 pp., John Wiley and Sons Ltd, Chichester, UK.

Fronzek, S., M. Luoto, and T. R. Carter. 2006. Potential effect of climate change on the distribution of palsa mires in subarctic Fennoscandia, Climate Research, 32: 1-12, DOI:10.3354/cr032001.

Gabrielsen, R. H., J. I. Faleide, C. Pascal, A. Braathen, J. P. Nystuen, B. Etzelmuller, and S. O'Donnell. 2010. Latest Caledonian to Present tectonomorphological development of southern Norway, Marine and Petroleum Geology, 27: 709-723, DOI:http://dx.doi.org/10.1016/j.marpetgeo.2009.06.004.

Gandin, L. S. 1965. Objective analysis of meteorological fields (Ob"ektivnyi analiz meteorologicheskikh polei), Translated from Russian by the Israel Program for Scientific Translations, Jerusalem.

Gisnås, K., B. Etzelmuller, H. Farbrot, T. V. Schuler, and S. Westermann. 2013. CryoGRID 1.0: Permafrost Distribution in Norway estimated by a Spatial Numerical Model, Permafrost and Periglacial Processes, 24: 2-19, DOI:10.1002/ppp.1765.

Gisnås, K., S. Westermann, T. V. Schuler, T. Litherland, K. Isaksen, J. Boike, and B. Etzelmüller. 2014. A statistical approach to represent small-scale variability of permafrost temperatures due to snow cover, The Cryosphere, 8: 2063-2074, DOI:10.5194/tc-8-2063-2014.

Gisnås, K., S. Westermann, S. T.V., K. Melvold, and B. Etzelmuller. 2016. Small-scale variation of snow in a regional permafrost model, The Cryoshpere .

Gruber, S. 2012. Derivation and analysis of a high-resolution estimate of global permafrost zonation, The Cryosphere, 6: 221, DOI:10.5194/tc-6-221-2012.

Haeberli, W. 1973. Die Basis-Temperatur der winterlichen Schneedecke als möglicher Indikator für die Verbreitung von Permafrost in den Alpen, Zeitschrift für Gletscherkunde und Glazialgeologie, 9: 221-227.

Harris, C., W. Haeberli, D. Mühll, and L. King. 2001. Permafrost monitoring in the high mountains of Europe: the PACE project in its global context, Permafrost and Periglacial Processes, 12: 3-11.

Heggem, E. S. F., H. Juliussen, and B. Etzelmüller. 2005. Mountain permafrost in centraleastern Norway, Norsk Geografisk Tidsskrift-Norwegian Journal of Geography, 59: 94-108.

Isaksen, K., H. Farbrot, L. Blikra, B. Johansen, J. Sollid, and T. Eiken. 2008. Five year ground surface temperature measurements in Finnmark, Northern Norway., In Ninth International Conference on Permafrost, Fairbanks, Alaska, June 29-July 3. Ed: D. L. Kane and K. M. Hinkel, Institute of Northern Engineering, University of Alaska, 1: 789-794

Isaksen, K., C. Hauck, E. Gudevang, R. S. Ødegård, and J. L. Sollid. 2002. Mountain permafrost distribution in Dovrefjell and Jotunheimen, southern Norway, based on BTS and DC resistivity tomography data, Norsk Geografisk Tidsskrift-Norwegian Journal of Geography, 56: 122-136, DOI:10.1080/002919502760056459.

Isaksen, K., P. Holmlund, J. Sollid, and C. Harris. 2001. Three deep alpine-permafrost boreholes in Svalbard and Scandinavia, Permafrost and Periglacial Processes, 12: 1325, DOI:10.1002/ppp.380

Johansson, M., T. R. Christensen, H. J. Akerman, and T. V. Callaghan. 2006. What Determines the Current Presence or Absence of Permafrost in the Torneträsk Region, a Sub-arctic Landscape in Northern Sweden?, AMBIO: A Journal of the Human 
Juliussen, H., and O. Humlum. 2007. Towards a TTOP ground temperature model for mountainous terrain in central-eastern Norway, Permafrost and Periglacial Processes, 18: 161-184.

King, L. 1982. Qualitative und quantitative Erfassung von Permafrost in Tarfala (Schwedisch Lappland) und Jotunheimen (Norwegen) mit Hilfe geoelektrischer Sondierungen, Zeitschrift für Geomorphologie, Supplement-Band 43: 139-160.

King, L. 1986. Zonation and Ecology of High Mountain Permafrost in Scandinavia, Geografiska Annaler. Series A, Physical Geography, 68: 131-139, DOI:10.2307/521452.

King, L., and M. Seppälä. 1987. Permafrost Thickness and Distribution in Finnish Lapland Results of Geoelectrical Soundings, Polarforschung, 57: 127-147.

King, L., and H. J. Åkerman. 1993. Mountain permafrost in Europe, In the Sixth International Conference on Permafrost, Beijing, China, July 5-9, South China University of Techology Press, 2: 1022-1027

Klein Tank, A., J. Wijngaard, G. Können, R. Böhm, G. Demarée, A. Gocheva, M. Mileta, S. Pashiardis, L. Hejkrlik, and C. Kern-Hansen. 2002. Daily dataset of 20th-century surface air temperature and precipitation series for the European Climate Assessment, International journal of climatology, 22: 1441-1453.

Krautblatter, M., D. Funk, and F. K. Günzel. 2013. Why permafrost rocks become unstable: a rock-ice-mechanical model in time and space, Earth Surf. Process. Landf., 38: 876887.

Kujala, K., M. Seppälä, and T. Holappa. 2008. Physical properties of peat and palsa formation, Cold Regions Science and Technology, 52: 408-414, DOI:http://dx.doi.org/10.1016/j.coldregions.2007.08.002.

Kukkonen, I., and J. Šafanda. 2001. Numerical modelling of permafrost in bedrock in northern Fennoscandia during the Holocene, Global and Planetary Change, 29: 259273, DOI:10.1016/S0921-8181(01)00094-7.

Lilleøren, K. S. 2016. Active rock glaciers at sea level in Finnmark, Northern Norway?, In 32nd Nordic Geological Winter Meeting, Helsinki, 13 - 15 January, 2016, The Geological Society of Finland. http://www.geologinenseura.fi/winter_meeting/abstracts_newnum_pdf/S15_13_195.p df

Lilleøren, K. S., and B. Etzelmüller. 2011. A regional inventory of rock glaciers and ice-cored moraines in Norway., Geografiska Annaler: Series A, Physical Geography, 93: 175191, DOI:10.1111/j.1468-0459.2011.00430.x.

Luoto, M., and M. Seppälä. 2002. Characteristics of earth hummocks (pounus) with and without permafrost in Finnish Lapland, Geografiska Annaler: Series A, Physical Geography, 84: 127-136, DOI:10.1111/1468-0459.00166.

Lussana, C., F. Uboldi, and M. R. Salvati. 2010. A spatial consistency test for surface observations from mesoscale meteorological networks, Quarterly Journal of the Royal Meteorological Society, 136: 1075-1088, DOI:10.1002/qj.622.

Majava, J. 2014. Modelling permafrost with BTS-method in Kilpisjärvi (in Finnish), University of Oulu, Finland.

Masson, D., and C. Frei. 2016. Long-term variations and trends of mesoscale precipitation in the Alps: recalculation and update for 1901-2008, International Journal of Climatology, 36: 492-500, DOI:10.1002/joc.4343.

Metsähallitus. 2002. Digital Biotope Data, Metsähallitus, Helsinki, Finland. 
Nelson, F. E., and S. I. Outcalt. 1987. A computational method for prediction and regionalization of permafrost, Arctic and Alpine Research 19: 279-288.

Ødegård, R., M. Hoelzle, K. Vedel Johansen, and J. Sollid. 1996. Permafrost mapping and prospecting in southern Norway, Norsk Geografisk Tidsskrift, 50: 41-54.

Ødegård, R. S., J. L. Sollid, and O. Liestøl. 1992. Ground temperature measurements in mountain permafrost, Jotunheimen, southern Norway, Permafrost and Periglacial Processes, 3: 231-234, DOI:10.1002/ppp.3430030310.

Olesen, O., J. Brönner, J. Ebbing, J. Gellein, L. Gernigon, J. Koziel, T. Lauritsen, R. Myklebust, C. Pascal, M. Sand, D. Solheim, and S. Usov. 2010. New aeromagnetic and gravity compilations from Norway and adjacent areas: methods and applications., in Petroleum Geology: From Mature Basins to New Frontiers-Proceedings of the 7th Petroleum Geology Conference, edited by B. A. Vining and S. C. Pickering, pp. 559586, Geological Society, London, DOI:10.1144/0070559.

Orlanski, I. 1975. A rational subdivision of scales for atmospheric processes, Bulletin of the American Meteorological Society, 56: 527-530, DOI:citeulike-article-id:12086670.

Ramberg, I. B., I. Bryhni, A. Nøttvedt, and K. Rangnes. 2006. The making of a land-geology of Norway, Geological Society of Norway, Trondheim.

Reusch, H. 1902. Vore dale og fjelde: hvorledes formen af Norges overflade er dannet (In Norwegian), 51 s. pp., John Griegs Bogtrykkeri, Bergen.

Ridefelt, H., B. Etzelmuller, J. Boelhouwers, and C. Jonasson. 2008. Statistic-empirical modelling of mountain permafrost distribution in the Abisko region, sub-Arctic northern Sweden, Norsk Geografisk Tidsskrift-Norwegian Journal of Geography, 62: 278-289, DOI:10.1080/00291950802517890.

Saloranta, T. M. 2012. Simulating snow maps for Norway: description and statistical evaluation of the seNorge snow model, The Cryosphere, 6: 1323-1337, DOI:10.5194/tc-6-1323-2012.

Sannel, A. B. K., G. Hugelius, P. Jansson, and P. Kuhry. 2015. Permafrost Warming in a Subarctic Peatland - Which Meteorological Controls are Most Important?, Permafrost and Periglacial Processesn/a-n/a, DOI:10.1002/ppp.1862.

Schuur, E. A. G., J. Bockheim, J. G. Canadell, E. Euskirchen, C. B. Field, S. V. Goryachkin, S. Hagemann, P. Kuhry, P. M. Lafleur, H. Lee, G. Mazhitova, F. E. Nelson, A. Rinke, V. E. Romanovsky, N. Shiklomanov, C. Tarnocai, S. Venevsky, J. G. Vogel, and S. A. Zimov. 2008. Vulnerability of Permafrost Carbon to Climate Change: Implications for the Global Carbon Cycle, BioScience, 58: 701-714, DOI:10.1641/b580807.

Seppälä, M. 1988. Palsas and related forms, in Advances in periglacial geomorphology, edited by M. J. Clark, pp. 247-278, John Wiley, Chichester.

Seppälä, M. 1997. Distribution of permafrost in Finland, Bulletin of the geological Society of Finland, 69: 87-96.

Seppälä, M. 2011. Synthesis of studies of palsa formation underlining the importance of local environmental and physical characteristics, Quaternary Research, 75: 366-370, DOI:http://dx.doi.org/10.1016/j.yqres.2010.09.007.

Skaugen, T., E. Alfnes, E. G. Langsholt, and H.-C. Udnæs. 2004. Time-variant snow distribution for use in hydrological models, Annals of Glaciology, 38: 180-186, DOI:10.3189/172756404781815013.

Smith, M. W., and D. W. Riseborough. 1996. Permafrost monitoring and detection of climate change, Permafrost and Periglacial Processes, 7: 301-309, DOI:10.1002/(SICI)10991530(199610) 7:4<301::AID-PPP231>3.0.CO;2-R.

Sollid, J. L., P. Holmlund, K. Isaksen, and C. Harris. 2000. Deep permafrost boreholes in western Svalbard, northern Sweden and southern Norway, Norsk Geografisk Tidsskrift - Norwegian Journal of Geography, 54: 186-191, DOI:10.1080/002919500448567. 
Sollid, J. L., K. Isaksen, T. Eiken, and R. S. Ødegård. 2003. The transition zone of mountain permafrost on Dovrefjell, southern Norway, In Eight International Conference on Permafrost, Zürich, Switzerland. Ed: M. Phillips, S. Springman and L. Arenson, Swets and Zeitlinger, Lisse, Proceedings Volume 2: 1085-1090

Thunis, P., and R. Bornstein. 1996. Hierarchy of Mesoscale Flow Assumptions and Equations, Journal of the Atmospheric Sciences, 53: 380-397, DOI:10.1175/15200469(1996)053<0380:HOMFAA>2.0.CO;2.

Uboldi, F., C. Lussana, and M. Salvati. 2008. Three-dimensional spatial interpolation of surface meteorological observations from high-resolution local networks, Meteorological Applications, 15: 331-345, DOI:10.1002/met.76.

Westermann, S., T. Østby, K. Gisnås, T. V. Schuler, and B. Etzelmüller. 2015. A ground temperature map of the North Atlantic permafrost region based on remote sensing and reanalysis data, The Cryosphere Discuss., 9: 753-790, DOI:10.5194/tcd-9-753-2015. 
881 Figure 1: Spatial distribution of mean annual air temperatures (left) and seasonal 882 maximum snow depths (right) averaged over the period $1981-2010$, based on the 883 NGCD dataset.

884 Figure 2: Boreholes with permafrost and seasonal frost are indicated with blue and 885 yellow dots, respectively, and basal temperature of snow (BTS)-surveys are outlined 886 in purple. The main sites of permafrost field investiagations are marked in letters: A 887 = Varangerhalvøya, $\mathrm{B}=$ Vaisjeaggi, $\mathrm{C}=$ Iskoras, $\mathrm{D}=$ Kilpisjärvi, $\mathrm{E}=$ Tavvavuoma, $\mathrm{F}$ 888 = Abisko, $\mathrm{G}=$ Tarfalaryggen, $\mathrm{H}=$ Dovrefjell, $\mathrm{I}=$ Elgåhogna, $\mathrm{J}=$ Sølen, $\mathrm{K}=$ 889 Juvvasshøe and central Jotunheimen, $\mathrm{L}=$ Finse, and $\mathrm{M}=$ Gaustatoppen. The lower 890 altitudinal limits of permafrost for the respective sites [m a.s.1.] are given in the 891 parenthesis behind the letters.

892 Figure 3: Schematic of the model setup.

893 Figure 4: Comparison of the permafrost map for the Scandinavian Peninsula, to the 894 International Permafrost Association Circum-Arctic permafrost map (Brown et al., 895 1997).The inset panel (lower right) is the continuation of the main map to the south. Figure 5: Lower altitudinal limits of permafrost (LALP) related to distance from the coast (left) in southern (S) and northern (N) Norway, and to latitude (right). Red, 898 blue and black lines indicate LALP for areas with $10 \%, 50 \%$ and $90 \%$ permafrost, 899 respectively.

900 Figure 6: Temperature validation at six permafrost sites in Scandinavia. Temperature 901 data from Abisko and Juvvasshøe weather stations are included in the interpolation 902 for the gridded weather data. 
903 Figure 7: Measured vs. modelled $M A G T$ at top of permafrost atall boreholes in 904 mountain areas in Scandinavia being part of the GTN-P. The error bars represent the $9052.5^{\text {th }}$ and the $97.5^{\text {th }}$ percentiles of all model realization; the dashed lines are the $\pm 2{ }^{\circ} \mathrm{C}$ 906 intervals around the 1:1 line (in solid). Figure 8: Comparison of modelled lower 907 altitudinal permafrost limits, here represented as percentage of modelled permafrost 908 per grid cell, and permafrost probability derived from BTS-surveys at Kilpisjärvi 909 (Majeva, 2014), Abisko (Ridefelt et al., 2008), Dovrefjell and Juvvasshøe (Isaksen et 910 al., 2002), and Elgåhogna and Sølen (Heggem et al., 2005). The $50 \%$ probability of 911 permafrost (thin, grey contour line) should correspond to the purple area in the 912 modelled permafrost zonation, while the $80 \%$ probability of permafrost (thick, black 913 contour line) should outline the dark blue area.

914 BTS-surveys at Kilpisjärvi (Majava, 2014), Abisko (Ridefelt et al., 2008), Dovrefjell and 915 Juvvasshøe (Isaksen et al., 2002), and Elgåhogna and Sølen (Heggem et al., 2005)

916 Figure 9: The distribution of elevation, maximum snow depths (Snow depth), 917 freezing and thawing degree days in the air (FDD/TDD) in locations mapped as 918 palsas (Palsas, green), modelled as permafrost in mires with snow free conditions 919 (PF mires, blue) and areas represented as mires in the CLC2012 raster map with 250 920 m resolution (Mires).

921 Figure 10: The graphs show running mean of annual thawing and freezing degree 922 days in the air (TDD and $F D D$ ), as well annual maximum snow depth (max SD), over 923 the 30-year period 1981 - 2010. Data are extracted from the NGCD dataset for the 924 four locations Vaisjeaggi, Abisko, Tarfalaryggen and Juvvasshøe (see Figure 2 for 925 locations). The stippled lines indicate the average values over each of the three 926 decades. 
927 Figure 11: The upper row is a comparison of modelled distribution of a) sporadic and 928 b) discontinuous permafrost in equilibrium with the climate of the three decades in 929 the period $1981-2010$. In the lower row the distribution of potential permafrost in 930 mires under "palsa conditions" is shown for northern Scandinavia (c) and Dovrefjell $931(d)$. 
Table 1: $\mathrm{n}$-factor classification assigned to surface cover classes in the $4^{\text {th }}$ CORINE Land Cover Map finalized

934 in 2012 (CLC12). The classification is based on Gisnås et al. (2013) and additional data from Tavvavuoma

935 (Sweden), Vaisjeaggi (Finland), Kilpisjärvi (Finland) and Iskoras (Norway). In open areas with sparse

936 vegetation cover, n-factors vary with maximum snow depth (SD) following the given functions. For mire and

937 peat, values for snow free conditions are given in the parenthesis.

\begin{tabular}{|c|c|c|c|c|}
\hline & Surface cover & ac12 & nT & $\overline{n F}$ \\
\hline 1 & Con'ferous forest & 312,313 & 0.95 & 0.35 \\
\hline 2 & $\begin{array}{l}\text { Broad-leaved forest, } \\
\text { transitional woodland and } \\
\text { shnub }\end{array}$ & 311,324 & 1.05 & 0.25 \\
\hline 3 & Mire and peat & 412,413 & $1.25(1.20)$ & $0.26(0.60)$ \\
\hline 4 & $\begin{array}{l}\text { Bedrodk and sparsely } \\
\text { vegetated area, glaciers }\end{array}$ & $\begin{array}{l}321,322,331,332 \\
333,334,335\end{array}$ & $\begin{array}{r}-0.14 * \mathrm{SD}+ \\
1.1\end{array}$ & $\begin{array}{r}-0.16 * \log (S D)+ \\
0.22\end{array}$ \\
\hline 5 & Blodkield & From sediment maps & $\begin{array}{r}-0.14 * S D+ \\
0.1\end{array}$ & $\begin{array}{r}-0.16 * \log (S D)+ \\
0.22\end{array}$ \\
\hline & $\begin{array}{l}\text { Agrialtural and artificial } \\
\text { surfaces, water bodies }\end{array}$ & $\begin{array}{l}100 \text { to } 299,500 \text { to } \\
599\end{array}$ & No Value & No Value \\
\hline
\end{tabular}

\begin{tabular}{rllll}
\hline ID & Surfidal Deposits & $\boldsymbol{\kappa}_{\mathbf{t}}$ & $\boldsymbol{\kappa}_{\mathbf{f}}$ & $\mathbf{\mathbf { k } _ { \mathbf { k } }}$ \\
\hline $\mathbf{2}$ & Beach and coastal deltas & 1,46 & 1,73 & 0,84 \\
$\mathbf{3}$ & Coarse and fine rubble / mountain alluvium and colluvium & 1,83 & 2,15 & 0,85 \\
$\mathbf{4}$ & Valley loess and alluvium / eolian & 1,57 & 1,80 & 0,87 \\
$\mathbf{5}$ & Uppland loess / eolian & 1,59 & 1,90 & 0,83 \\
$\mathbf{6}$ & Lightly modified moraine & 1,47 & 2,13 & 0,69 \\
$\mathbf{7}$ & Current moraine / glacial moraines \& drift & 1,52 & 1,87 & 0,81 \\
$\mathbf{1 1}$ & Glaciofluvial deposits & 1,97 & 2,05 & 0,96 \\
$\mathbf{1 2}$ & Galciolacustrine deposits & 1,65 & 2,23 & 0,74 \\
$\mathbf{1 3}$ & Glacio - fluvial deposits & 1,45 & 1,88 & 0,77 \\
$\mathbf{1 6}$ & Fluvial deposits & 1,65 & 1,99 & 0,83 \\
$\mathbf{1 7}$ & Undifferentiated alluvium \& colluvium & 1,43 & 1,82 & 0,79 \\
$\mathbf{1 8}$ & Coastal delta / coastal & 1,86 & 2,11 & 0,88 \\
$\mathbf{1 9}$ & Fine rubble, mountain alluvium \& colluvium & 1,87 & 2,13 & 0,88 \\
$\mathbf{2 0}$ & Weathering material & 1,96 & 2,16 & 0,91 \\
$\mathbf{2 1}$ & Eolian deposits & 1,98 & 2,01 & 0,99 \\
$\mathbf{2 2}$ & Old marine \& alluvium / coastal & 1,41 & 1,97 & 0,72 \\
$\mathbf{2 6}$ & Highly modified moraine / glacial moraines \& drift & 1,91 & 1,92 & 1,00 \\
\hline
\end{tabular}




\begin{tabular}{llrrr}
\hline $\mathbf{2 7}$ & M ires and peat, thick & 0,37 & 0,50 & 0,74 \\
$\mathbf{2 8}$ & Mires and peat, thin & 1,65 & 2,23 & 0,74 \\
$\mathbf{2 9}$ & Bedrock & 3,50 & 3,50 & 1,00 \\
$\mathbf{3 0}$ & Blockfield & 2,95 & 3,00 & 0,98 \\
$\mathbf{3 1}$ & Thin sediment class / dry moraine & 3,00 & 3,00 & 1,00 \\
\hline
\end{tabular}

941 